\title{
The effect of water source and soil supplementation on parasite contamination in organic vegetable gardens
}

O efeito da fonte de água e suplementação de solo na contaminação parasitária em hortas orgânicas

Fernanda Pinto Ferreira ${ }^{1 *}$; Eloiza Teles Caldart ${ }^{1}$; Roberta Lemos Freire'; Regina Mitsuka-Breganó1;

Felipe Machado de Freitas ${ }^{2}$; Ana Carolina Miura ${ }^{1}$; Marcelle Mareze ${ }^{1}$; Felippe Danyel Cardoso Martins ${ }^{1}$;

Mariana Ragassi Urbano ${ }^{3}$; Adilson Luiz Seifert ${ }^{2}$; Italmar Teodorico Navarro ${ }^{1}$

\author{
${ }^{1}$ Departamento de Medicina Veterinária Preventiva, Universidade Estadual de Londrina - UEL, Londrina, PR, Brasil \\ ${ }^{2}$ Departamento de Agronomia, Universidade Estadual de Londrina - UEL, Londrina, PR, Brasil \\ ${ }^{3}$ Departamento de Estatística, Universidade Estadual de Londrina - UEL, Londrina, PR, Brasil
}

Received March 21, 2018

Accepted June 12, 2018

\begin{abstract}
The objective of this study was to determine factors associated with vegetable contamination with zoonotic protozoan. Samples of water, soil and vegetables were collected from July/2014 to May/2016, totaling 83 samples, 21 properties of Londrina region, Paraná, Brazil. DNA amplification of Toxoplasma gondii, Cryptosporidium spp. and Giardia intestinalis in the samples was conducted using polymerase chain reaction (PCR). The PCR results were positive for T. gondii in $12.9 \%$ (8/62), Cryptosporidium spp. in 11.3\% (7/62) and G. intestinalis in 25.8\% (16/62) of the samples. DNA sequencing identified C. parvum in five samples and G. intestinalis Assemblage $\mathrm{E}$ in three. The statistical associations demonstrated greater probability of positive samples for T. gondii and for at least one of the three protozoa when the source of irrigation water was the river; a greater chance of positive samples for Cryptosporidium spp. when deer were present on the property; and a smaller chance of positive samples for at least one of the three etiologic agents when soil was supplemented with limestone. The results expose some critical contamination points, providing support for training farmers on good management practices during the production process.
\end{abstract}

Keywords: Vegetables, water, environmental contamination, Cryptosporidium spp., Toxoplasma gondii, Giardia intestinalis.

\section{Resumo}

O trabalho teve como objetivo determinar os fatores associados à contaminação de vegetais por protozoários zoonóticos. Amostras de água, solo e vegetais foram coletadas de julho/2014 a maio/2016, totalizando 83 amostras de 21 propriedades da regiâo de Londrina, Paraná, Brasil. A amplificação de fragmentos de DNA de T. gondii, Cryptosporidium spp. e Giardia intestinalis foi realizada por meio da reação em cadeia da polimerase (PCR). Os resultados da PCR foram positivos para T. gondii em 12,9\% (8/62), Cryptosporidium spp. em 11,3\% (7/62) e G. intestinalis. em 25,8\% (16/62) das amostras. O sequenciamento de DNA identificou C. parvum em cinco amostras e G. intestinalis, Assemblage E em três amostras. As associaçóes estatísticas evidenciaram maior probabilidade de amostras serem positivas para T. gondii ou para pelo menos um dos três protozoários quando a fonte de água de irrigação era o rio; uma maior chance de amostras positivas para Cryptosporidium spp. quando havia cervos na propriedade; e uma menor chance das amostras serem positivas para pelo menos um dos três agentes etiológicos quando o solo era suplementado com calcário. Os resultados expóem alguns pontos críticos de contaminação, fornecendo suporte para capacitar os agricultores em boas práticas de gestão durante o processo de produção.

Palavras-chave: Legumes, água, contaminação ambiental, Cryptosporidium spp., Toxoplasma gondii, Giardia intestinalis. 


\section{Introduction}

Vegetables, including all vegetables grown in gardens, are foods rich in vitamins, carbohydrates, fiber and minerals; are easy to digest; and offer high satiety, a high antioxidant content and a low caloric content. Due to their nutritional importance, vegetables are essential in human nutrition (SINGH et al., 2001; WORTHINGTON, 2001).

In Brazil, vegetables are produced commonly by the conventional farming system; however, in recent years there was an important growth in organic cultivation. It is mainly related to the search for healthier food, with better quality and flavor, environmental preservation and pesticides' free (ARCHANJO et al., 2001). The main differences between organic and conventional cultivation are the use, in the latter, of agricultural pesticides, chemical fertilizers and genetically modified organisms. Organic agriculture excludes these elements from the production process, using natural implements and predators (BOURN \& PRESCOTT, 2002; GARCIA \& TEIXEIRA, 2017; GOMIERO et al., 2011; WILKINS \& HILLERS, 1994).

Contamination of vegetables can occur during production, transportation, storage and commercialization; however, cultivation conditions involving the quality of irrigation water, fertilizer type, the presence of animals in the property and direct contamination from farm workers are the main risk points (ALMEIDA et al., 2013; AMAHMID et al., 1999; CHAIDEZ et al., 2005; DIXON et al., 2013; DIXON, 2016).

Toxoplasmosis is one of the most common parasitic zoonoses in the world, and it can affect all warm-blooded animals, presenting a wide variability in clinical outcomes (DUBEY, 2010). Cryptosporidiosis and giardiasis are zoonoses and are described as important causes of diarrhea (FAYER, 1997; PEDROSO \& AMARANTE, 2006). In an immunocompetent individual, these diseases may assume a self-limiting characteristic with clinical manifestations of low expression, but in an immunocompromised patient they may manifest in a severe and prolonged form (MITSUKA-BREGANÓ et al., 2010; PEDROSO \& AMARANTE, 2006; SHIKANI \& WEISS, 2014). The description of these protozoa in food and waterborne outbreaks (BERGER et al., 2010; CHEUN et al., 2013; MAC KENZIE et al., 1994; SILVA et al., 2005; VAUDAUX et al., 2010; YEUNG et al., 2013) highlights the importance of leafy vegetables, which are consumed in natura and facilitate the transmission of these protozoa and other pathogens.

Considering the health benefits of consuming vegetables, their greater inclusion in the diet of people worldwide and their risk as a source of zoonotic protozoa such as $T$. gondii, Cryptosporidium spp. and $G$. intestinalis, this work aimed to evaluate the contamination and hygienic-sanitary conditions of their production in organic gardens.

\section{Materials and Methods}

The study was carried out from July 2014 to May 2016 on 21 horticultural properties of the municipalities of Apucarana, Marilândia do Sul, Ortigueira, Rolândia and Londrina (District of Guaravera), in the state of Paraná (Figure 1). As an inclusion criterion, small commercial vegetable-producing organic properties were assisted by the Organic Certification Project of the State University of Londrina. On eleven properties, water and vegetable samples were collected, and soil samples were included on the other properties.

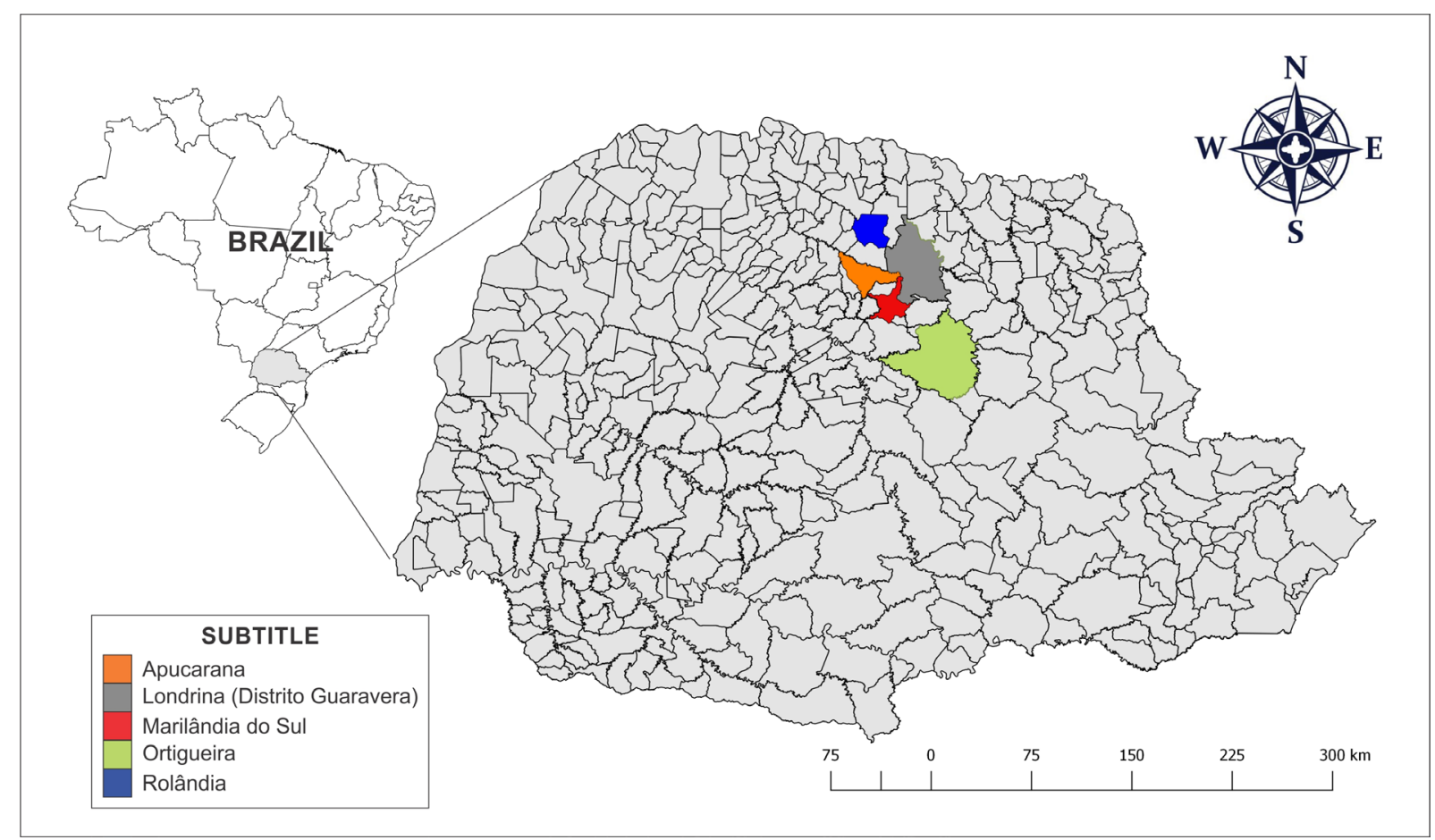

Figure 1. Map of Paraná highlighting the municipalities where samples of vegetables, water and soil were collected and submitted for parasitological and microbiological research from 2014 to 2016, Paraná, Brazil. 


\section{Obtaining and analyzing samples of vegetables}

Forty-two clumps of leafy vegetables were randomly collected, two per property (from property 1 to 21 ), packed in plastic bags and kept in refrigeration. For T. gondii, Cryptosporidium spp. and $G$. intestinalis detection, $50 \mathrm{~g}$ of the leaves were washed in $300 \mathrm{~mL}$ of $1 \%$ Tween 80 extraction solution in a plastic bag under manual shaking for 10 minutes and then filtered into $500 \mathrm{~mL}$ glass beakers through two layers of gauze. The wash was divided into conical tubes and subjected twice to centrifugation at $2100 \mathrm{x}$ g for 10 minutes. The pellet was aliquoted into microtubes and stored at $-20{ }^{\circ} \mathrm{C}$ until DNA extraction.

\section{Obtaining and analyzing soil samples}

For T. gondii, Cryptosporidium spp. and G. intestinalis detection, a total of 10 samples of approximately $10 \mathrm{~g}$ of soil, collected from the surface, one per property (from property 12 to 21 ) and stored in $50 \mathrm{~mL}$ conical tubes with $30 \mathrm{~mL}$ of $1 \mathrm{M}$ glycine, were homogenized with the aid of a stirrer for 30 minutes. They were then kept at rest for five minutes for sedimentation. After the pellet was discarded, the supernatant was centrifuged at $1500 \mathrm{x} g$ for 15 minutes. The final concentrate was aliquoted into microtubes and stored at $-20^{\circ} \mathrm{C}$ until DNA extraction.

\section{Obtaining and analyzing water samples}

For the microbiological analysis by means of the chromogenic substrate technique (APHA, 2005), 21 samples of water, one per property (from property 1 to 21 ), were collected from the irrigation tap of the vegetable gardens, as recommended by the protocol in Brazil (BRASIL, 2013).

For T. gondii, Cryptosporidium spp. and $G$. intestinalis detection, a total of 10 samples (from property 12 to 21 ) of $10 \mathrm{~mL}$ were collected in clean plastic bottles from irrigation tap. The water was filtered through a cellulose ester membrane with a $47 \mathrm{~mm}$-diameter and $1.2 \mu \mathrm{m}$ porosity (Millipore ${ }^{\oplus}$, Billerica, Massachusetts, USA) in a filter holder system using a vacuum pump ( $4 \mathrm{~L} / \mathrm{min})$. After filtration, the material was eluted in $0.1 \%$ Tween 80 with the aid of flexible plastic loops (Thermo Fisher Scientific, Massachusetts, USA) (BRANCO et al., 2012). The obtained material was concentrated by centrifugation twice at $1050 \mathrm{xg}$ for $15 \mathrm{~min}$ at $4^{\circ} \mathrm{C}$. The obtained pellet was stored in microtubes at $-20^{\circ} \mathrm{C}$ until DNA extraction.

\section{Molecular analyses}

The samples were previously submitted to freeze-thaw ( 5 cycles of freezing at $-80{ }^{\circ} \mathrm{C}$ and thawing at $56{ }^{\circ} \mathrm{C}$ ), then DNA extraction was performed using a commercial kit (NucleoSpin Tissue $^{\circledast}$, Macherey-Nagel, Düren, Germany) in accordance with the manufacturer's instructions and DNA was collected in a final volume of $100 \mu \mathrm{L}$. DNA extracted were stored at $-20^{\circ} \mathrm{C}$ until polymerase chain reaction (PCR) processing.

PCR assays for $T$. gondii were performed as previously described by Homan et al. (2000), to amplify a fragment of
529 bp. Cryptosporidium spp. were detected using a nested-PCR reaction with primers described by Xiao et al. (1999), which target a fragment of $18 \mathrm{~S}$ rRNA gene between 826 and $840 \mathrm{bp}$. For $G$. intestinalis DNA detection, the samples were subjected to nested-PCR to amplify an approximately 300-bp fragment of the $18 \mathrm{~S}$ rRNA gene from $G$. intestinalis (COKLIN et al., 2007), in addition to $530 \mathrm{bp}$ of the TPI (triose-phosphate isomerase) gene with primers described by Sulaiman et al. (2003) and 432 bp of the GDH (glutamate dehydrogenase) gene with primers described by Read et al. (2004) in a semi-nested PCR.

PCR products were visualized by $1.5 \%$ agarose gel electrophoresis stained with SYBR Safe DNA (Invitrogen ${ }^{\circledR}$, California, USA). In addition, when positive for Cryptosporidium spp. and for $G$. intestinalis, the PCR products were purified using the QIAquick PCR Purification Kit (QIAGEN, Hilden, Germany), and the DNA was quantified by a Picodrop (Thermo Fisher Scientific, Wilmington, USA). DNA sequencing was performed with the BigDye Terminator v.3.1 Cycle Sequencing Kit (Applied Biosystems, Carlsbad, USA) with the corresponding forward or reverse primers on a 3500 genetic analyzer (Applied Biosystems, Carlsbad, USA), according to the instructions of the manufacturer. The sequences obtained were examined with PHRED software (EWING \& GREEN, 1998) and inspected with CHROMAS software for quality analysis of chromatograms. Consensus sequences were determined by the CAP3 software (http://asparagin.cenargen. embrapa.br/cgi-bin/phph/cap3.pl), and their identities were compared to the sequences deposited in GenBank using BLAST software (CAMACHO et al., 2009). The nucleotide sequence data reported in this article were deposited in GenBank under the following accession numbers: Cryptosporidium parvum (MF353924 to MF353928) and Giardia intestinalis (MF425817 to MF425819). The phylogenetic relationships between $G$. intestinalis sequences of the present study and GenBank standard sequences were characterized by the alignment of 390 nucleotides of the GDH coding gene using the maximum likelihood method with 250 bootstraps in the MEGA 4.0 program. The tree was rooted with Giardia ardeae (AF069060) and the GenBank sequences used in this tree are standards of assemblages A1 (AY178735), A2 (AY178737), B (AY826193), D (U60986), E (AY178741) and $\mathrm{F}$ (AF069057).

\section{Statistical Analysis}

A semi-structured questionnaire was applied to all horticulturists participating in the study, who were questioned about the type of planting and fertilization, soil supplementation, presence of animals on the property, irrigation system, toilet and sewage characteristics. The program EpiInfo 3.5.4 (DEAN et al., 1990) was used to tabulate the variables together with the microbiological and molecular results found. Statistical analysis was performed using the EpiInfo programs 3.5.4 and R 3.3.2 (R CORE TEAM, 2013) by means of the Chi-square test or Fisher's exact test, where appropriate. The analysis of these associations with a control of the confounding variables was performed applying simple and multiple logistic regression analysis (HOSMER et al., 2013). Only the variables whose p-values were less than 0.10 in the 
screening analysis and had some biological meaning were included in the logistic regression models. The association measurement was obtained by the Odds Ratio (OR) calculation with a $95 \%$ confidence interval (CI). The multiple correspondence analysis was performed with program R 3.3.3 (R CORE TEAM, 2013) through the FactoMineR (HAIR et al., 2009) package, an exploratory technique that does not rely on statistical tests but allows the visualization of the most important relationships of a large set of variables among each other (HOFFMAN \& FRANKE, 1986). In addition, it can help in visualizing the multivariate relationship between the categories of the different variables, and their geometric proximity in the graph, suggesting the possibility of associations between them.

\section{Results}

In total, 83 samples were collected, being 42 of vegetables, 31 of water ( 21 for microbiological analysis and 10 for parasitological analysis) and 10 of soil; from 21 properties of the municipalities of Apucarana (6/21), Marilândia do Sul (7/21), Ortigueira (6/21), Rolândia (1/21) and Londrina (District of Guaravera) (1/21). Among the leafy vegetables, 17 samples were of crisp lettuce (Lactuca sativa), seven of arugula (Eruca sativa), nine of chicory (Cichorium intybus and Cichorium endivia), five of chives (Allium fistulosum), two of purple lettuce, one spinach (Spinacia oleracea) and one chard (Beta vulgaris subsp. Vulgaris). On the first eleven properties, water was not submitted for molecular analysis, and no soil samples were collected.
Eighteen properties were organic cultivation certified, and three $(14.3 \%)$ were in the certification phase. The organic fertilizer source was variable among the properties: $23.8 \%(5 / 21)$ used chicken manure, $14.3 \%(3 / 21)$ used mixed manure, $14.3 \%(3 / 21)$ used chicken litter, $14.3 \%(3 / 21)$ used commercial compounds and $33.3 \%$ (7/21) used bovine manure. Eleven $(52.3 \%)$ of the properties underwent mineral supplementation on a regular basis, six with limestone $(54.5 \%)$, three with a potassium supplement $(27.2 \%)$ and one with mineral present in the fertilizer.

Wild birds and domestic animals, such as dogs, cats, horses, and cattle, were present on all the properties studied, and in five $(23.8 \%)$ of them, the animals had access to the gardens. Wild animals, such as cervids, hare, armadillos, capybara, fox and cougar were present on 13 of the studied properties (61.9\%). All the properties were washing their vegetables: $52.4 \%(11 / 21)$ of the properties in treated tap water and $47.6 \%(10 / 21)$ in rinsing tanks. Irrigation in $57.1 \%(13 / 21)$ was automated. The source of irrigation water on $57.1 \%(12 / 21)$ of the properties was spring, $14.3 \%(3 / 21)$ of the properties used untreated river water, and $28.6 \%(6 / 21)$ of the properties used artesian wells.

Of the water samples, $95.2 \%(20 / 21)$ presented total coliforms, with a variation of 1 to $>2419.6$ CTNMP/100 mL; for CTT and Escherichia coli, $76.2 \%(16 / 21)$ of the samples were positive, ranging from 1 to 218.7 CTTNMP/100 mL.

Regarding the PCR results, $12.9 \%$ (8/62) of the samples were positive for T. gondii, $11.3 \%$ (7/62) for Cryptosporidium spp., and $25.8 \%(16 / 62)$ for $G$. intestinalis (two in TPI, seven in GDH, five in 18S rRNA and two in TPI and GDH) (Table 1). It was possible to identify the parasite species by DNA sequencing in

Table 1. Vegetable, water and soil samples positive for the protozoa Toxoplasma gondii, Cryptosporidium spp. and Giardia intestinalis from organic crop properties, from 2014 to 2016 in Paraná, Brazil. Results are based on molecular analyses.

\begin{tabular}{|c|c|c|c|c|c|c|c|c|c|c|}
\hline \multirow{2}{*}{ Property } & \multirow{2}{*}{ Municipality } & \multicolumn{3}{|c|}{ Toxoplasma gondii } & \multicolumn{3}{|c|}{ Cryptosporidium spp. } & \multicolumn{3}{|c|}{ G. intestinalis } \\
\hline & & Vegetable & Soil & Water & Vegetable & Soil & Water & Vegetable & Soil & Water \\
\hline 1 & Marilândia do Sul & - & NT & NT & - & NT & NT & + Let & NT & NT \\
\hline 2 & Marilândia do Sul & + Let & NT & NT & - & NT & NT & + Aru & NT & NT \\
\hline 3 & Marilândia do Sul & - & NT & NT & - & NT & NT & - & NT & NT \\
\hline 4 & Marilândia do Sul & + Let & NT & NT & + Aru* $^{*}$ & NT & NT & $+\mathrm{Let}^{* *}+\mathrm{Aru}^{* *}$ & NT & NT \\
\hline 5 & Guaravera & + Let Aru & NT & NT & - & NT & NT & + Let $^{* *}$ & NT & NT \\
\hline 6 & Ortigueira & - & NT & NT & - & NT & NT & - & NT & NT \\
\hline 7 & Ortigueira & - & NT & NT & - & NT & NT & - & NT & NT \\
\hline 8 & Ortigueira & - & NT & NT & - & NT & NT & - & NT & NT \\
\hline 9 & Ortigueira & - & NT & NT & - & NT & NT & - & NT & NT \\
\hline 10 & Ortigueira & - & NT & NT & - & NT & NT & - & NT & NT \\
\hline 11 & Ortigueira & - & NT & NT & - & NT & NT & + Chic & NT & NT \\
\hline 12 & Rolândia & - & + & - & - & - & - & + Chic & - & - \\
\hline 13 & Apucarana & - & - & + & - & - & - & + Chic & + & - \\
\hline 14 & Apucarana & - & - & - & - & - & $+^{*}$ & - & - & + \\
\hline 15 & Apucarana & - & - & - & - & - & - & + Let & - & - \\
\hline 16 & Apucarana & - & + & + & - & $+^{*}$ & $+^{*}$ & + Chiv & + & + \\
\hline 17 & Apucarana & - & - & - & - & - & $+^{*}$ & - & - & + \\
\hline 18 & Marilândia do Sul & - & - & - & - & - & - & + Cha & - & - \\
\hline 19 & Marilândia do Sul & - & - & - & - & - & - & - & - & - \\
\hline 20 & Marilândia do Sul & - & - & - & + Let & - & - & - & - & - \\
\hline 21 & Apucarana & - & - & - & - & + & - & - & - & - \\
\hline
\end{tabular}

NT: Not tested; + positive sample; - negative sample; Let: Lettuce; Aru: Arugula; Cha: Chard; Chic: Chicory; Chiv: Chive. ${ }^{*}$ C. parvum or ${ }^{* *} G$. intestinalis Assemblage E confirmed by the DNA results from Sanger sequencing. 
seven of the positive samples. C. parvum was the species present in three water samples and one soil sample sample showing $100 \%$ of similarity with other sequences from GenBank. G. intestinalis Assemblage E was present in two vegetable samples showing 99\% of similarity with other sequences from GenBank. In order to confirm the $G$. intestinalis Assemblage, the phylogenetic analysis with the partial sequences of the GDH gene of $G$. intestinalis obtained was performed, a clustering of samples with standard sequences of Assemblage E (Figure 2), commonly associated with giardiasis in cattle, was observed. In other PCR-positive samples, there was no success in sequencing due to the low amount of DNA.

Factors associated with the presence of DNA of zoonotic protozoa such as $T$. gondii, Cryptosporidium spp. and $G$. intestinalis in vegetables, soil and water are listed in Tables 2, 3 and 4.
The graph generated by the multiple correspondence analysis (Figure 3) confirmed the main findings of this study related to the risk factors for the presence of zoonotic protozoa in vegetables, water and soil of properties with organic production systems. It is shown in dimension one of the graph ( $\mathrm{x}$-axis) that the categories of negative variables for T. gondii, Cryptosporidium spp. and $G$. intestinalis and at least one of the three zoonotic protozoa in question are on the left along with the categories of limestone supplementation, spring water source and absence of cervids. On the other hand, on the right side of the graph we have the categories of positive variables for T. gondii, G. intestinalis, Cryptosporidium spp. and at least one of the three zoonotic protozoa together with the categories of potassium and fertilizer supplementation, river water source and the presence of cervids. The interpretation of

Table 2. Characteristics of the organic vegetable producing properties of northern Paraná, Brazil, significantly associated with the occurrence of Toxoplasma gondii and Giardia intestinalis.

\begin{tabular}{|c|c|c|c|}
\hline \multirow{2}{*}{ Toxoplasma gondii } & \multirow{2}{*}{ Positive/Total (\%) } & \multicolumn{2}{|c|}{ Univariate Logistic Regression } \\
\hline & & p-Value & O.R. Gross (CI 95\%) \\
\hline Water Source & & $<0.05$ & \\
\hline Spring & $1 / 34(2.9)$ & & 1.00 \\
\hline Well & $4 / 22(18.2)$ & & $7.11(0.74-68.57)$ \\
\hline River & $3 / 6(50.0)$ & & $32.00(2.49-411.45)$ \\
\hline G. intestinalis & Positive/Total (\%) & p-Value & O.R. Gross (CI 95\%) \\
\hline Cryptosporidium spp. positive & & $<0.05$ & \\
\hline No & $11 / 55(20.0)$ & & 1.00 \\
\hline Yes & $5 / 7(71.4)$ & & $10.00(1.71-58.59)$ \\
\hline
\end{tabular}

Table 3. Characteristics of the organic vegetable producing properties of northern Paraná, Brazil, significantly associated with the occurrence of Cryptosporidium spp.

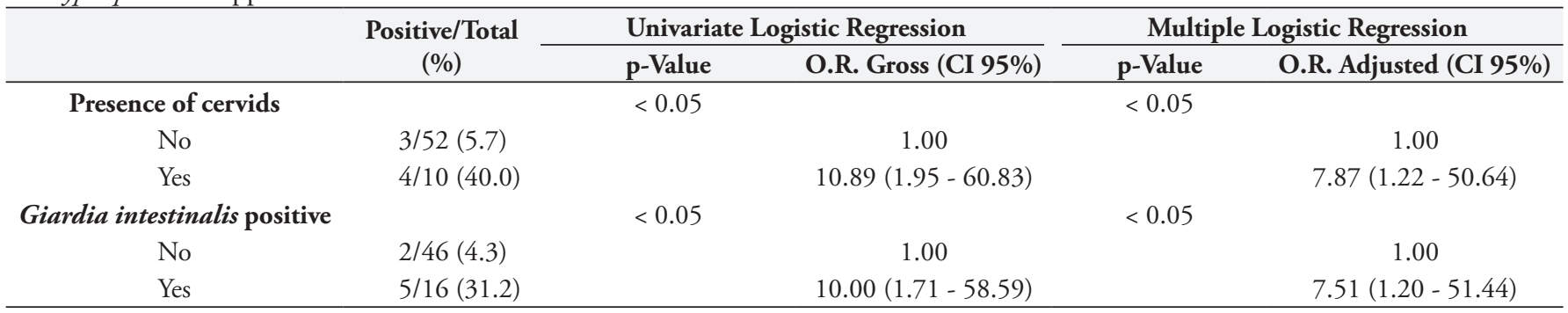

Table 4. Characteristics of the organic vegetable producing properties of northern Paraná, Brazil, significantly associated with the occurrence of at least one of the protozoa (Toxoplasma gondii, Cryptosporidium spp. or G. intestinalis).

\begin{tabular}{|c|c|c|c|}
\hline & \multirow{2}{*}{ Positive/Total (\%) } & \multicolumn{2}{|c|}{ Univariate Logistic Regression } \\
\hline & & p-Value & O.R. Gross (CI 95\%) \\
\hline Type of supplement & & $<0.05$ & \\
\hline Not supplemented & $15 / 38(39.5)$ & & 1.00 \\
\hline Limestone & $1 / 16(6.2)$ & & $0.10(0.01-0.85)$ \\
\hline Potassium Base & $4 / 6(66.7)$ & & $3.07(0.50-18.89)$ \\
\hline Water source & & $<0.05$ & \\
\hline Spring & $7 / 34(20.6)$ & & 1.00 \\
\hline Well & $10 / 22(45.4)$ & & $3.21(0.98-10.47)$ \\
\hline River & $5 / 6(83.3)$ & & $19.28(1.92-192.82)$ \\
\hline
\end{tabular}




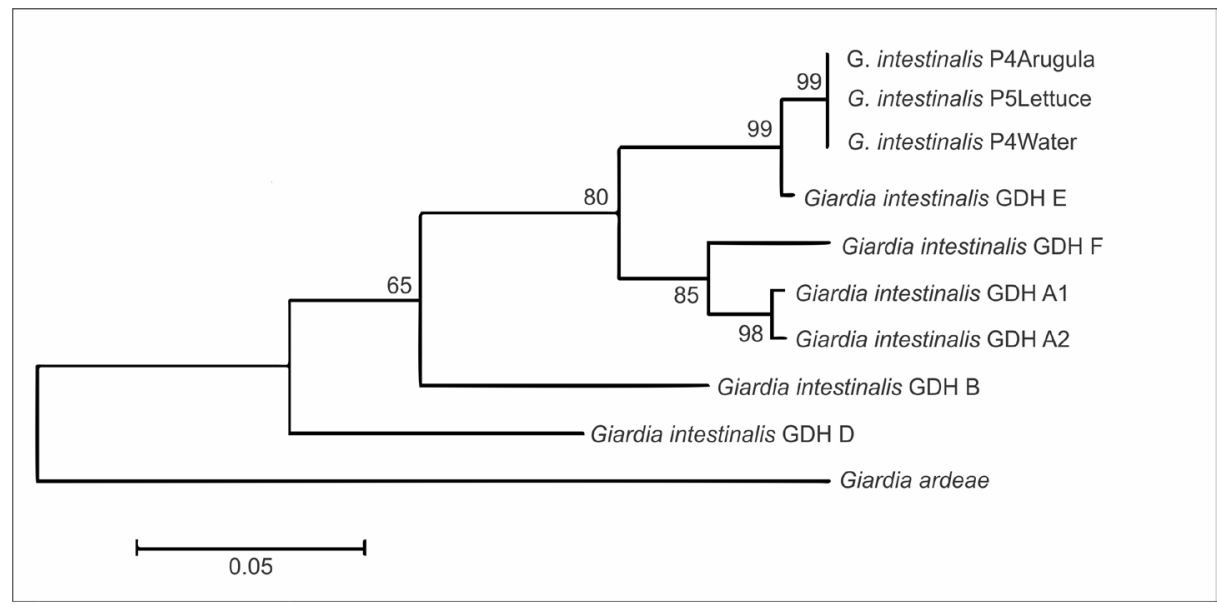

Figure 2. Phylogenetic relationships among $G$. intestinalis isolates characterized by the alignment of 390 nucleotides of the GDH coding gene using the maximum likelihood method with 250 bootstraps in the MEGA 4.0 program. The tree is rooted with Giardia ardeae (AF069060), and the GenBank sequences used in this tree are standards of the assemblies A1 (AY178735), A2 (AY178737), B (AY826193), D (U60986), E (AY178741) and F (AF069057).

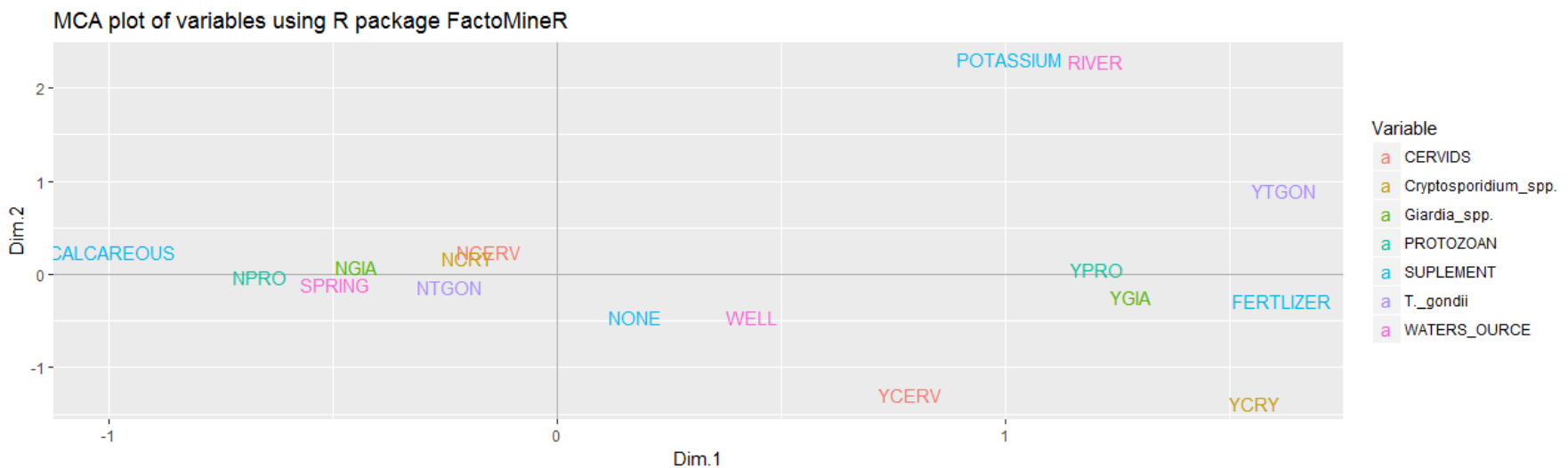

Figure 3. Graph resulting from the multiple correspondence analysis. Presence of cervids (NCERV, YCERV); positive results of T. gondii (NTGON, YTGON), Cryptosporidium spp. (NCRY, YCRY), Giardia spp. (NGIA, YGIA), and one of the three protozoa (NPRO, YPRO); water source (SPRING, WELL, RIVER) and supplement used in growing (LIMESTONE, NONE, POTASSIUM and FERTILIZER).

dimension two (y-axis) of the graph was not possible due to the lack of biological meaning.

\section{Discussion}

Resolution 357/05 of CONAMA (National Council for the Environment) (BRASIL, 2005) recommends that for the irrigation of vegetables and fruits with development on the ground, the Thermotolerant coliforms (CTT) count should not exceed 200/100 mL; Escherichia coli is the main species of the CTT group, whose exclusive habitat is the intestine (BRASIL, 2005). E. coli was present in $76.2 \%(16 / 21)$ of the analyzed water samples, and of these, $18.7 \%$ (3/16), one of spring (209.8 CTNMP/100mL), one of river $(328.2 \mathrm{CTNMP} / 100 \mathrm{~mL})$ and another of artesian well (201.2 CTNMP/100mL), with higher counts than that allowed by the resolution. The use of faecal indicators, particularly, E. coli, is a better practical approach to identify contaminated water sources or food (ALLENDE \& MONAGHAN, 2015; NATARO \& KAPER, 1998). Recent studies associate the presence of parasites such as $G$. intestinalis and Cryptosporidium spp. to the presence of CTT (TOLEDO et al., 2017) in the water, indicating the necessity of monitoring parasite presence in vegetable gardens for the production of innocuous vegetables.

Regarding the PCR results, $12.9 \%$ (8/62) of the samples had DNA fragments compatible with $T$. gondii, and of these, $50.0 \%$ (4/8) were vegetables, $25.0 \%$ (2/8) were water and $25.0 \%(2 / 8)$ were soil. Lass et al. (2012) studied T. gondii in 216 fruits and vegetables in Poland and observed a frequency of $9.7 \%$ positive samples. The eight positive samples came from six properties, of which $50.0 \%(3 / 6)$ had cats, all with access to the cultivation area, suggesting direct contamination of vegetables by definitive hosts on these properties (FRENKEL et al., 1970). In vegetable gardens that did not have cats $(3 / 6)$, the source of irrigation water from the river may have influenced the contamination due to the flow during rains, when the river receives several fecal pathogens 
from domestic and wild animals (WELLS et al., 2015); its use in irrigation should be avoided, unless it is properly treated. Water was related to outbreaks of human toxoplasmosis previously in Panamá (BENENSON et al., 1982), Canada (BOWIE et al., 1997), Atlanta (DUBEY et al., 1981) and Brazil (VAUDAUX et al., 2010). The use of treated water with regular microbiological analysis is essential to ensure its quality and safe use in irrigation.

From the analyzed samples, $11.3 \%(7 / 62)$ were positive for Cryptosporidium spp. Of these, 42,9\% (3/7) water samples (two of artesian well and one of spring), 28.6\% (2/7) soil sample and $28,6 \%(2 / 7)$ vegetable sample were identified as containing C. parvum, an important zoonotic species and the main cause of human cryptosporidiosis, which represents a threat to public health because it is associated with diarrhea and death in immunocompromised individuals (SANTÍN, 2013). The main known reservoirs are production and wild animals (RYAN et al., 2014). In this study, the presence of cervids on the properties was associated with the presence of Cryptosporidium spp., which could explain environmental contamination by water drained. Wells et al. (2015), when conducting a study in a water supply network in Scotland, detected C. parvum and related the high prevalence of the protozoan to cervids inhabiting the region studied. Ranjbar-Bahadori et al., (2013) suggested that plants may provide a route of infection by Cryptosporidium spp. for humans when they observed a frequency of 6.6\% (33/496) positive samples with risk factors related to the type of vegetable and irrigation water in gardens of Tehran, Iran. Poulton et al. (1991) suggested that the fertilizer used in agriculture was one of the main sources responsible for the high levels of oocysts of Cryptosporidium spp. observed in the River Thames in the south of England. In this study, the type of fertilizers used on the positive properties were $50.0 \%$ (3/6) chicken litter, 16.7\% (1/6) bovine manure and $33.3 \%$ (2/6) mixed manure (chicken and bovine), the type of fertilizer had no statistical association with positivity by Cryptosporidium spp., however the parasite was previously described in these animals (AL MAWLY et al., 2015; EWALD et al., 2017; HELMY et al., 2017).

$G$. intestinalis was found in $25.8 \%(16 / 62)$ of the analyzed samples, of which 12 samples were vegetables, two were water of artesian well and two were soil, on nine properties. The presence of cysts of $G$. intestinalis at any stage of the production of vegetables is of extreme concern, as this parasite is resistant in the environment, remaining viable for weeks or months (ALMEIDA et al., 2010). The $G$. intestinalis samples from the present study showed similarity to the Assemblage E (Figure 2), commonly described in cattle (EY et al., 1997; PLUTZER et al., 2010). Fertilization using bovine or mixed manure may facilitate environmental contamination when not properly processed. Taking into account that infected young animals can release up to $10^{6}$ cysts per gram of feces (GEURDEN et al., 2010), the presence of bovine animals on a farm may lead to contamination of soil and water, since environmental contamination may precede the contamination of water and vegetables (ALMEIDA et al., 2010). The three positive samples for non-zoonotic Assemblage E came from vegetables (two lettuces, one arugula) from two properties that did not have cattle, so the contamination could have occurred due to the use of bovine fertilizer on one of the properties or by contaminated irrigation water in both.

Statistically, there was a significant association between being positive for Cryptosporidium spp. and $G$. intestinalis, we suggest that this association may be due to the fact that both pathogens are known to be water-borne. Before the 1980s, diseases of bacterial and viral origin were associated with water, but with the inclusion of chlorination in the treatment process, there was an effective reduction of these microorganisms (FURTADO et al., 1998). In contrast, Cryptosporidium spp. and G. intestinalis have become the main etiological agents of water transport and the cause of outbreaks (CHEUN et al., 2013; MAC KENZIE et al., 1994). They are of great importance in public health because of their low infective doses, resistance to conventional water treatment and adverse environmental conditions (SLIFKO et al., 2000). Water, once contaminated, acts as an efficient carrier of pathogens, either because of its great dispersion capacity or because of its direct and indirect compulsory consumption (FRANCO, et al., 2012). Wild animals play an important role in the contamination of water by their aquatic activities or by feces flowing to the rivers and springs (HAMNES et al., 2006; WELLS et al., 2015).

Vegetables do not develop in soil with acidic $\mathrm{pH}$, which is the case of Brazilian soil (ERNANI et al., 2002). Acidic soils are neutralized, most of the times, by the application of limestone (ALBUQUERQUE et al., 2003; PRADO \& FERNANDES, 2000). The use of this supplement was a factor associated with a lower chance of positive samples for at least one of the three parasitic agents studied, it is known that its use reduces the viability of helminth eggs (CAPIZZI-BANAS et al., 2004). Franco et al. (2012) have described that the use of alkaline reagents in water, such as calcium carbonate, can produce deformations in cysts of $G$. intestinalis and oocysts of Cryptosporidium spp. Transferring this description to this study, the direct contact of the limestone with the cysts and oocysts for a prolonged period may have led to their deformation, DNA exposure and degradation, thus diminishing the positive samples on these properties. Further studies are needed to clarify this result.

Among the analyzed gardens, 57.1\% (12/21) presented at least one of the protozoa studied, and with respect to the samples, the frequency was $52.5 \%(22 / 42)$ in vegetables, $20.0 \%(2 / 10)$ in soil and 20.0\% (2/10) in water. As in Falavigna et al. (2005), there was no significant difference between the types of leafy greens tested. Commonly used decontamination treatments, such as vinegar and sodium hypochlorite (YUCEL SENGUN \& KARAPINAR, 2005), are not able to destroy the resistant forms of T. gondii, Cryptosporidium spp., and Giardia spp. (HUNTER \& THOMPSON, 2005). The morphological characteristics of leafy vegetables, such as compact structure and presence of multiple leaves facilitate a greater fixation by parasites, making manual mechanical cleaning difficult (FALAVIGNA et al., 2005). According to Guilherme et al. (1999), the clarification of food safety to producers is extremely important because it is a determining factor for the production of safe food.

The main forms of contamination of fruits and vegetables during production are fertilizer (ALMEIDA et al., 2013; ERDOGRUL \& SENER., 2005), direct contamination from farm workers, access of wild animals (WELLS et al., 2015) and 
domestic animals to gardens, and contaminated irrigation water (BERALDO \& FARACHE, 2011; CHAIDEZ et al., 2005), the latter was a factor associated with the presence on the samples of at least one of the agents. River water, in turn, had a greater number of positive samples than expected; the use of this type of water for irrigation is a big problem in Brazil (MAROUELLI \& SILVA, 1998), because a significant number of rivers are polluted, probably due to the extensive area of agriculture and livestock around the surface water sources and the contamination by untreated municipal effluents, mainly sewage, constituting another important vehicle of transmission and dissemination of pathogens (AMORÓS et al., 2010; BERALDO \& FARACHE, 2011; DIXON et al., 2013; MAROUELLI \& SILVA, 1998; SILVA et al., 2005). Toledo et al. (2017) in a study in dairy farms in Paraná, Brazil, observed that the absence of vegetation and protective structures around the springs was associated with the frequency of positive water samples to Cryptosporidium spp. and $G$. intestinalis. The vegetation around the springs acts as a physical barrier, thus reducing the drainage of animal waste and other contaminants (TOLEDO et al., 2017). Most of the springs visited in this study were protected, which may have been an important factor for a smaller number of positive samples than expected in this source.

Of the 12 properties with at least one positive sample for one of the three agents, $66.7 \%(8 / 12)$ produced their own fertilizer with bovine manure or chicken litter, and of these, $87.5 \%(7 / 8)$ did not respect the period of composting. The maturity of the compost is related to the complete microbiological decomposition and the transformation of the organic matter into humus, and this process occurs after approximately 90 days of tanning; correct composting can promote the inactivation of some pathogens (DÉPORTES et al., 1998; KIEHL, 1998; VINNERÅS et al., 2003). Inadequate fertilizer production, in addition to causing contamination of vegetables and water, prevents the inactivation of pathogens present in the raw material, making the fertilizer unfit for use in edible vegetables.

\section{Conclusion}

The control of parasitological contamination of raw vegetables is a major challenge, since contamination can occur in all the stages that precede arrival to the consumers' table. The results indicate that inadequate hygienic-sanitary conditions in organic gardens, as well as the risk of infection by protozoa are of public health importance. In addition, the results expose some of the points of contamination risk, such as the water source, soil supplementation and presence of animals on properties. Thus, there is a need to raise awareness among producers and consumers about the implementation of good handling practices during the cultivation process and before the time of consumption.

\section{Acknowledgements}

We would like to acknowledge the CNPQ (National Research Council) for granting the doctoral scholarship.

\section{References}

Albuquerque JA, Bayer C, Ernani PR, Mafra AL, Fontana EC. Aplicação de calcário e fósforo e estabilidade da estrutura de um solo ácido. Rev Bras Ciênc Solo 2003; 27(5): 799-806. http://dx.doi.org/10.1590/S010006832003000500004.

Allende A, Monaghan J. Irrigation water quality for leafy crops: a perspective of risks and potential solutions. Int J Environ Res Public Health 2015; 12(7): 7457-7477. http://dx.doi.org/10.3390/ijerph120707457. PMid:26151764.

Al Mawly J, Grinberg A, Velathanthiri N, French N. Cross sectional study of prevalence, genetic diversity and zoonotic potential of Cryptosporidium parvum cycling in New Zealand dairy farms. Parasit Vectors 2015; 8(240): 1-7. http://dx.doi.org/10.1186/s13071-015-0855-9. PMid:25896433.

Almeida A, Pozio E, Cacciò SM. Genotyping of Giardia duodenalis cysts by new real-time PCR assays for detection of mixed infections in human samples. Appl Environ Microbiol 2010; 76(6): 1895-1901. http://dx.doi. org/10.1128/AEM.02305-09. PMid:20080999.

Almeida AJ, Lima VS, Rodrigues ABF, Di Filippo PA. Contamination with Cryptosporidium spp. in manure used as fertilizer in urban gardens. Rev Port Ciênc Vet 2013; 108(585-586): 23-27.

Amahmid O, Asmama S, Bouhoum K. The effect of waste water reuse in irrigation on the contamination level of food crops by Giardia cysts and Ascaris eggs. Int J Food Microbiol 1999; 49(1-2): 19-26. http://dx.doi. org/10.1016/S0168-1605(99)00058-6. PMid:10477066.

Amorós I, Alonso JL, Cuesta G. Cryptosporidium oocysts and Giardia cysts on salad products irrigated with contaminated water. J Food Prot 2010; 73(6): 1138-1140. http://dx.doi.org/10.4315/0362-028X-73.6.1138. PMid:20537274.

APHA. Standard methods for the examination of water and wastewater. Washington, DC; 2005.

Archanjo LR, Brito KFW, Sauerbeck S. Alimentos orgânicos em Curitiba: consumo e significado. Rev Cad Debate 2001; 8: 1-6.

Benenson MW, Takafuji ET, Lemon SM, Greenup RL, Sulzer AJ. Oocysttransmitted toxoplasmosis associated with ingestion of contaminated water. NEngl J Med 1982; 307(11): 666-669. http://dx.doi.org/10.1056/ NEJM198209093071107. PMid:7110216.

Beraldo RM, Farache A Fo. Bacteriological quality of irrigation water from vegetable gardens in the Municipalities of Araraquara, Boa Esperança do Sul and Ibitinga, SP. Aliment Nutr 2011; 22(3): 345-350.

Berger CN, Sodha SV, Shaw RK, Griffin PM, Pink D, Hand P, et al. Fresh fruit and vegetables as vehicles for the transmission of human pathogens. Environ Microbiol 2010; 12(9): 2385-2397. http://dx.doi. org/10.1111/j.1462-2920.2010.02297.x. PMid:20636374.

Bowie WR, King AS, Werker DH, Isaac-Renton JL, Bell A, Eng SB, et al. Outbreak of toxoplasmosis associated with municipal drinking water. Lancet 1997; 350(9072): 173-177. http://dx.doi.org/10.1016/S01406736(96)11105-3. PMid:9250185.

Bourn D, Prescott J. A comparison of the nutritional value, sensory qualities, and food safety of organically and conventionally produced foods. Crit Rev Food Sci Nutr 2002; 42(1): 1-34. http://dx.doi. org/10.1080/10408690290825439. PMid:11833635.

Branco N, Leal DAG, Franco RMB. A parasitological survey of natural water springs and inhabitants of a tourist city in southeastern Brazil. Vector 
Borne Zoonotic Dis 2012; 12(5): 410-417. http://dx.doi.org/10.1089/ vbz.2011.0679. PMid:22217166.

Brasil. Ministério da Saúde, Fundação Nacional de Saúde, Departamento de Saúde Ambiental, Coordenação de Controle da Qualidade da Água. Manual prático de análise de água. [Online]. 4. ed. Brasília: FUNASA; 2013. [cited 2018 Jun 13]. Available from: http://www.funasa.gov.br/ site/wp-content/files_mf/manual_pratico_de_analise_de_agua_2.pdf

Camacho C, Coulouris G, Avagyan V, Ma N, Papadopoulos J, Bealer $\mathrm{K}$, et al. BLAST+: architecture and applications. BMC Bioinformatics 2009; 10(1): 421. http://dx.doi.org/10.1186/1471-2105-10-421. PMid:20003500.

Capizzi-Banas S, Deloge M, Remy M, Schwartzbrod J. Liming as an advanced treatment for sludge sanitisation: helminth eggs elimination - Ascaris eggs as model. Water Res 2004; 38(14-15): 3251-3258. http:// dx.doi.org/10.1016/j.watres.2004.04.015. PMid:15276741.

Chaidez C, Soto M, Gortares P, Mena K. Occurrence of Cryptosporidium and Giardia in irrigation water and its impact on the fresh produce industry. Int J Environ Health Res 2005; 15(5): 339-345. http://dx.doi. org/10.1080/09603120500289010. PMid:16416751.

Cheun H-I, Kim C-H, Cho S-H, Ma D-W, Goo B-L, Na MS, et al. The first outbreak of giardiasis with drinking water in Korea. Osong Public Health Res Perspect 2013; 4(2): 89-92. http://dx.doi.org/10.1016/j. phrp.2013.03.003. PMid:24159537.

Coklin T, Farber J, Parrington L, Dixon B. Prevalence and molecular characterization of Giardia duodenalis and Cryptosporidium spp. in dairy cattle in Ontario, Canada. Vet Parasitol 2007; 150(4): 297-305. http:// dx.doi.org/10.1016/j.vetpar.2007.09.014. PMid:17964724.

Brasil. Conselho Nacional do Meio Ambiente - CONAMA. Resolução no 357 de 18 de março de 2005. Dispóe sobre a classificação dos corpos de água e diretrizes ambientais para o seu enquadramento, bem como estabelece as condições e padrões de lançamento de efluentes, e dá outras providências. [online]. Diário Oficial da República Federativa do Brasil, Brasília, 2005 [cited 2018 Feb 10]. Available from: http://www.mma. gov.br/port/conama/res/res05/res35705.pdf

Dean AG, Dean JA, Burton AH, Discker RC. Epi-Info, Version 5: a word processing, database, and statistics programme for epidemiology on microcomputers. Atlanta, GA USD Inc.; 1990.

Déportes I, Benoit-Guyod JL, Zmirou D, Bouvier MC. Microbial disinfection capacity of municipal solid waste (MSW) composting. J Appl Microbiol 1998; 85(2): 238-246. http://dx.doi.org/10.1046/j.13652672.1998.00484.x. PMid:9750296.

Dixon BR. Parasitic illnesses associated with the consumption of fresh produce - an emerging issue in developed countries. Curr Opin Food Sci 2016; 8: 104-109. http://dx.doi.org/10.1016/j.cofs.2016.04.009.

Dixon B, Parrington L, Cook A, Pollari F, Farber J. Detection of Cyclospora, Cryptosporidium, and Giardia in Ready-to-Eat Packaged Leafy Greens in Ontario, Canada. J Food Prot 2013; 76(2): 307-313. http://dx.doi. org/10.4315/0362-028X.JFP-12-282. PMid:23433379.

Dubey JP, Sharma SP, Juranek DD, Sulzer AJ, Teutsch SM. Characterization of Toxoplasma gondii isolates from an outbreak of toxoplasmosis in Atlanta, Georgia. Am J Vet Res 1981; 42(6): 1007-1010. PMid:7283229.

Dubey JP. Toxoplasmosis of Animals and Humans. Maryland: CRC Press; 2010.

Erdogrul O, Sener H. The contamination of various fruit and vegetable with Enterobius vermicularis, Ascaris eggs, Entamoeba histolyca cysts and Giardia cysts. Food Control 2005; 16(6): 559-562.
Ernani PR, Bayer C, Maestri L. Corn yield as affected by liming and tillage system on an acid Brazilian Oxisol. Agron J2002; 94(2): 305-309. http://dx.doi.org/10.2134/agronj2002.0305.

Ewald MPC, Martins FDC, Caldart ET, Vieira FEG, Yamamura MH, Sasse JP, et al. The first study of molecular prevalence and species characterization of Cryptosporidium in free-range chicken (Gallus gallus domesticus) from Brazil. Rev Bras Parasitol Vet 2017; 26(4): 472-478. http://dx.doi.org/10.1590/s1984-29612017068. PMid:29185602.

Ewing B, Green P. Base-calling of automated sequencer traces using phred. II Error probabilities. Genome Res 1998; 8(3): 186-194. http:// dx.doi.org/10.1101/gr.8.3.186. PMid:9521922.

Ey PL, Mansouri M, Kulda J, Nohýnková E, Monis PT, Andrews $\mathrm{RH}$, et al. Genetic analysis of Giardia from hoofed farm animals reveals artiodactyl-specific and potentially zoonotic genotypes. J Eukaryot Microbiol 1997; 44(6): 626-635. http://dx.doi.org/10.1111/j.1550-7408.1997. tb05970.x. PMid:9435134.

Guilherme AL, Araújo SM, Falavigna DL, Pupulim AR, Dias ML, Oliveira HS, et al. Prevalência de enteroparasitas em horticultores e hortaliças da Feira do Produtor de Maringá, Paraná. Rev Soc Bras Med Trop 1999; 32(4): 405-411. http://dx.doi.org/10.1590/S0037-86821999000400012. PMid:10495671.

Falavigna LM, Freitas CBR, Melo GC, Nishi L, Araújo SM, FalavignaGuilherme AL. Qualidade de hortaliças comercializadas no noroeste do Paraná, Brasil. Parasitol Latinoam 2005; 60(3-4): 144-149.

Fayer R. Cryptosporidium and Cryptosporidiosis. Maryland: CRC Press; 1997.

Franco RMB, Branco N, Leal DAG. Parasitologia Ambiental: Métodos de concentraçáo e detecção de Cryptosporidium spp. e Giardia spp. em amostras de água. Rev Patol Trop 2012; 41(2): 119-135. http://dx.doi. org/10.5216/rpt.v41i2.19320.

Frenkel JK, Dubey JP, Miller NL. Toxoplasma gondii in cats: fecal stages identified as coccidian oocysts. Science 1970; 167(3919): 893-896. http:// dx.doi.org/10.1126/science.167.3919.893. PMid:4903651.

Furtado C, Adak GK, Stuart JM, Wall PG, Evans HS, Casemore DP. Outbreaks of waterborne infectious intestinal disease in England and Wales, 1992-5. Epidemiol Infect 1998; 121(1): 109-119. http://dx.doi. org/10.1017/S0950268898001083. PMid:9747762.

Garcia JM, Teixeira P. Organic versus conventional food: A comparison regarding food safety. Food Rev Int 2017; 33(4): 424-446. http://dx.doi. org/10.1080/87559129.2016.1196490.

Geurden T, Vercruysse J, Claerebout E. Is Giardia a significant pathogen in production animals? Exp Parasitol 2010; 124(1): 98-106. http://dx.doi. org/10.1016/j.exppara.2009.03.001. PMid:19285075.

Gomiero T, Pimentel D, Paoletti MG. Environmental Impact of Different Agricultural Management Practices: Conventional vs. Organic Agriculture. Crit Rev Plant Sci 2011; 30(1-2): 95-124. http://dx.doi.org/10.1080/0 7352689.2011 .554355 .

Hair JF, Black WC, Babin BJ, Anderson RE, Tatham RL. Análise multivariada de dados. Porto Alegre: Bookman Editora; 2009.

Hamnes IS, Gjerde B, Robertson L, Vikøren T, Handeland K. Prevalence of Cryptosporidium and Giardia in free-ranging wild cervids in Norway. Vet Parasitol 2006; 141(1-2): 30-41. http://dx.doi.org/10.1016/j. vetpar.2006.05.004. PMid:16797126.

Helmy YA, Krücken J, Abdelwhab ESM, von Samson-Himmelstjerna G, Hafez HM. Molecular diagnosis and characterization of Cryptosporidium spp. in turkeys and chickens in Germany reveals evidence for previously 
undetected parasite species. PLoS One 2017; 12(6): e0177150. http:// dx.doi.org/10.1371/journal.pone.0177150. PMid:28575116.

Hoffman DL, Franke GR. Correspondence analysis: graphical representation of categorical data in marketing research. J Mark Res 1986; 23(3): 213 227. http://dx.doi.org/10.2307/3151480.

Homan WL, Vercammen M, De Braekeleer J, Verschueren H. Identification of a 200- to 300-fold repetitive 529 bp DNA fragment in Toxoplasma gondii, and its use for diagnostic and quantitative PCR. Int J Parasitol 2000; 30(1): 69-75. http://dx.doi.org/10.1016/S0020-7519(99)001708. PMid:10675747.

Hosmer DW Jr, Lemeshow S, Sturdivant RX. Applied logistic regression. New Jersey: John Wiley \& Sons; 2013. http://dx.doi.org/10.1002/9781118548387.

Hunter PR, Thompson RCA. The zoonotic transmission of Giardia and Cryptosporidium. Int J Parasitol 2005; 35(11-12): 1181-1190. http:// dx.doi.org/10.1016/j.ijpara.2005.07.009. PMid:16159658.

Kiehl EJM. Manual de compostagem: maturação e qualidade do composto. Piracicaba; 1998.

Lass A, Pietkiewicz H, Szostakowska B, Myjak P. The first detection of Toxoplasma gondii DNA in environmental fruits and vegetables samples. Eur J Clin Microbiol Infect Dis 2012; 31(6): 1101-1108. http://dx.doi. org/10.1007/s10096-011-1414-8. PMid:21948336.

Mac Kenzie WR, Hoxie NJ, Proctor ME, Gradus MS, Blair KA, Peterson DE, et al. Massive outbreak in Milwaukee of Cryptosporidium infection transmitted through the public water supply. $N$ Engl J Med 1994; 331(3): 161-167. http://dx.doi.org/10.1056/NEJM199407213310304. PMid:7818640.

Marouelli WA, Silva HR. Aspectos sanitários da água para fins de irrigação. [online]. Brasília: EMBRAPA; 1998. (Comunicado Técnico; vol. 5). [cited 2017 Dec 10]. Available from: https://ainfo.cnptia.embrapa.br/digital/ bitstream/item/107307/1/Aspectos-sanitarios-da-agua-para-fins.pdf.

Mitsuka-Breganó R, Lopes-Mori FMR, Navarro IT. Toxoplasmose adquirida na gestação e congênita: vigilância em saúde, diagnóstico, tratamento e condutas. Londrina: Eduel; 2010. http://dx.doi.org/10.7476/9788572166768.

Nataro JP, Kaper JB. Diarrheagenic Escherichia coli. Clin Microbiol Rev 1998; 11(1): 142-201. PMid:9457432.

Pedroso RF, Amarante MK. Giardíase: aspectos parasitológicos e imunológicos. Biosaúde 2006; 8(1): 61-71.

Plutzer J, Ongerth J, Karanis P. Giardia taxonomy, phylogeny and epidemiology: facts and open questions. Int J Hyg Environ Health 2010; 213(5): 321-333. http://dx.doi.org/10.1016/j.ijheh.2010.06.005. PMid:20619729.

Poulton M, Colbourne J, Dennis PJ. Thames water's experiences with Cryptosporidium. Water Sci Technol 1991; 24(2): 21-26. http://dx.doi. org/10.2166/wst.1991.0023.

Prado RM, Fernandes FM. Escória de siderurgia e calcário na correção da acidez do solo cultivado com cana-de-açúcar em vaso. Sci Agric 2000; 57(4): 739-744. http://dx.doi.org/10.1590/S0103-90162000000400023.

R Core Team. A language and environment for statistical computing [online]. 2013. [cited 2017 Dec 10] Available from: http//www.R-project.org

Ranjbar-Bahadori S, Mostoophi A, Shemshadi B. Study on Cryptosporidium contamination in vegetable farms around Tehran. Trop Biomed 2013; 30(2): 193-198. PMid:23959484.
Read C, Monis P, Andrewthompson R. Discrimination of all genotypes of Giardia duodenalis at the glutamate dehydrogenase locus using PCRRFLP. Infect Genet Evol 2004; 4(2): 125-130. http://dx.doi.org/10.1016/j. meegid.2004.02.001. PMid:15157630.

Ryan U, Fayer R, Xiao L. Cryptosporidium species in humans and animals: current understanding and research needs. Parasitology 2014; 141(13): 1667-1685. http://dx.doi.org/10.1017/S0031182014001085. PMid:25111501.

Santín M. Clinical and subclinical infections with Cryptosporidium in animals. $N Z$ Vet J 2013; 61(1): 1-10. http://dx.doi.org/10.1080/0048 0169.2012.731681. PMid:23134088.

Shikani H, Weiss LM. Human cryptosporidiosis: a clinical perspective. In: Cacció SM, Widmer G. Cryptosporidium: parasite and disease. 1st ed. New York: Springer; 2014. p. 383-421. http://dx.doi.org/10.1007/9783-7091-1562-6_9.

Singh G, Kawatra A, Sehgal S. Nutritional composition of selected green leafy vegetables, herbs and carrots. Plant Foods Hum Nutr 2001; 56(4): 359-364. http://dx.doi.org/10.1023/A:1011873119620. PMid:11678441.

Silva CGM, Andrade SAC, Stamford TLM. Occurrence of Cryptosporidium spp. and others parasites in vegetables consumed in natura, Recife, Brazil. Cien Saude Colet 2005; 10(Suppl): 63-69. http://dx.doi.org/10.1590/ S1413-81232005000500009.

Slifko TR, Smith HV, Rose JB. Emerging parasite zoonoses associated with water and food. Int J Parasitol 2000; 30(12-13): 1379-1393. http:// dx.doi.org/10.1016/S0020-7519(00)00128-4. PMid:11113263.

Sulaiman IM, Fayer R, Bern C, Gilman RH, Trout JM, Schantz PM, et al. Triosephosphate Isomerase Gene Characterization and Potential Zoonotic Transmission of Giardia duodenalis. Emerg Infect Dis 2003; 9 (11): 1444 1452. http://dx.doi.org/10.3201/eid0911.030084. PMid:14718089.

Toledo RDS, Martins FDC, Ferreira FP, de Almeida JC, Ogawa L, Dos Santos HL, et al. Cryptosporidium spp. and Giardia spp. in feces and water and the associated exposure factors on dairy farms. PLoS One 2017; 12(4): e0175311. http://dx.doi.org/10.1371/journal.pone.0175311. PMid:28403147.

Vaudaux JD, Muccioli C, James ER, Silveira C, Magargal SL, Jung C, et al. Identification of an atypical strain of Toxoplasma gondii as the cause of a waterborne outbreak of toxoplasmosis in Santa Isabel do Ivai, Brazil. J Infect Dis 2010; 202(8): 1226-1233. http://dx.doi.org/10.1086/656397. PMid:20836703.

Vinnerås B, Björklund A, Jönsson $\mathrm{H}$. Thermal composting of faecal matter as treatment and possible disinfection method - Laboratory-scale and pilot-scale studies. Bioresour Technol 2003; 88(1): 47-54. http://dx.doi. org/10.1016/S0960-8524(02)00268-7. PMid:12573563.

Wells B, Shaw H, Hotchkiss E, Gilray J, Ayton R, Green J, et al. Prevalence, species identification and genotyping Cryptosporidium from livestock and deer in a catchment in the Cairngorms with a history of a contaminated public water supply. Parasit Vectors 2015; 8(1): 66. http:// dx.doi.org/10.1186/s13071-015-0684-x. PMid:25650114.

Wilkins JL, Hillers VN. Influences of pesticide residue and environmental concerns on organic food preference among food cooperative members and non-members in Washington State. J Nutr Educ 1994; 26(1): 26-33. http://dx.doi.org/10.1016/S0022-3182(12)80831-4.

Worthington V. Nutritional quality of organic versus conventional fruits, vegetables, and grains. J Altern Complement Med 2001; 7(2): 161-173. http://dx.doi.org/10.1089/107555301750164244. PMid:11327522. 
Xiao L, Escalante L, Yang C, Sulaiman I, Escalante AA, Montali RJ, et al. Phylogenetic analysis of Cryptosporidium parasites based on the smallsubunit rRNA gene locus. Appl Environ Microbiol 1999; 65(4): 15781583. PMid: 10103253.

Yeung NW, Hayes K, Cowie RH. Effects of washing produce contaminated with the snail and slug hosts of Angiostrongylus cantonensis with three common household solutions. Hawaii J Med Public Health 2013;72(6 Suppl2): 83-86. PMid:23901391.

Yucel Sengun I, Karapinar M. Effectiveness of household natural sanitizers in the elimination of Salmonella typhimurium on rocket (Eruca sativa Miller) and spring onion (Allium cepa L.). Int J Food Microbiol 2005; 98(3): 319-323. http://dx.doi.org/10.1016/j.ijfoodmicro.2004.07.011. PMid:15698693. 